\title{
Prevalence and influencing risk factors of eczema among preschool children in Urumqi city: a cross-sectional survey
}

\author{
Haonan Shi ${ }^{1 \dagger}$, Guangsheng Wan ${ }^{2 \dagger}$, Tingting Wang ${ }^{2 *}$, Jia Zhu ${ }^{3}$, Lan Jiang ${ }^{4}$, Shaowei Ma ${ }^{1}$, Jian Yao ${ }^{1}$, Zhe Yin ${ }^{1}$,
} Murizhati Maimaiti ${ }^{1}$ and Huijuan Dong ${ }^{1}$

\begin{abstract}
Background: Eczema is a chronic inflammatory disease associated with impaired quality of life. We identified indoor environmental risk factors, to provide strong evidence for the prevention and control of eczema in preschool children.

Methods: Using a cross-sectional study with stratified random cluster sampling, we conducted a self-administered questionnaire survey among 8153 parents of children aged 2-8 years in 60 kindergartens in six districts of Urumqi city during August 2019.

Results: Among 8153 preschool children, 12.0\% of the children have been diagnosed with eczema. Multivariate logistic regression analysis showed that caesarean section (odds ratio $[\mathrm{OR}]=1.18,95 \%$ confidence interval [Cl]: 1.03-1.36), being an only child ( $\mathrm{OR}=1.36,95 \% \mathrm{Cl}$ : 1.18-1.57), presence of mould or moisture in the mother's home before pregnancy $(\mathrm{OR}=1.53,95 \% \mathrm{Cl}: 1.17-2.00)$, presence of flies or mosquitoes in the dwelling currently $(\mathrm{OR}=$ $1.31,95 \% \mathrm{Cl}: 1.10-1.55)$, pets kept in the child's home currently $(\mathrm{OR}=1.23,95 \% \mathrm{Cl}: 1.01-1.51)$, presence of pets during child's first year ( $\mathrm{OR}=1.45,95 \% \mathrm{Cl}: 1.14-1.85)$, and family history of eczema (OR $=3.53,95 \% \mathrm{Cl}: 2.98-4.19)$ are the risk factors for the development of eczema, whereas ethnicity other than the Han Chinese $(\mathrm{OR}=0.77,95 \%$ Cl: 0.61-0.96) is a protective factor for eczema.

Conclusion: Preschool children in Urumqi are at a high risk of eczema, particularly those of the Han Chinese ethnicity. Parents should be attentive to the indoor living environment of children and take actions to reduce indoor humidity, pest control and elimination, and avoid raising pets to reduce the risk of development of eczema in children.
\end{abstract}

Keywords: Indoor environment, Preschool children, Eczema, Pets

\section{Background}

Eczema is an allergic skin condition with symptoms including skin damage, swelling, itchiness and recurrent rashes. The symptoms in children have a complex aetiology, usually believed as combination of environmental

\footnotetext{
* Correspondence: m18909929590_1@163.com

+Haonan Shi and Guangsheng Wan contributed equally to this work.

${ }^{2}$ School of Nursing \& Health Management, Shanghai University of Medicine

\& Health Sciences, No.279, Zhouzhu Highway, Pudong New District,

Shanghai 201318, China

Full list of author information is available at the end of the article
}

and genetic factors [1]. Eczema causes itchiness, which can lead to sleep disturbances in children and even affect physical and mental development in severe cases. Eczema can progress into asthma or rhinitis; moreover, the treatment of eczema and its triggering factors can impose an economic burden on the patient [2-4].

Many domestic and international studies have analysed the factors associated with the prevalence of eczema in preschool children. A study conducted in 10 provinces and cities in China, which was a survey

(c) The Author(s). 2021 Open Access This article is licensed under a Creative Commons Attribution 4.0 International License, which permits use, sharing, adaptation, distribution and reproduction in any medium or format, as long as you give appropriate credit to the original author(s) and the source, provide a link to the Creative Commons licence, and indicate if changes were made. The images or other third party material in this article are included in the article's Creative Commons licence, unless indicated otherwise in a credit line to the material. If material is not included in the article's Creative Commons licence and your intended use is not permitted by statutory regulation or exceeds the permitted use, you will need to obtain permission directly from the copyright holder. To view a copy of this licence, visit http://creativecommons.org/licenses/by/4.0/ The Creative Commons Public Domain Dedication waiver (http://creativecommons.org/publicdomain/zero/1.0/) applies to the data made available in this article, unless otherwise stated in a credit line to the data. 
analysis of acute allergies and eczema, showed that the prevalence of eczema in children ranged from 4.8 to $15.8 \%$ [5]. In contrast, two studies in the United States and Sweden showed that the prevalence of eczema was 20 and 23\%, respectively [6, 7]. In recent years, China's economy has developed rapidly, the demand for housing has increased, and a large number of families are keeping pets at home. Eczema has been associated with animal contact, poor ventilation, and living in large urban areas having heavy traffic [8]. Located in the central part of Xinjiang, Urumqi is a multi-ethnic city with a hot and dry climate. Moreover, due to the specific lifestyle of the people in Xinjiang, the incidence of asthma, pneumonia, and allergic rhinitis is relatively high [5, 9]; however, large-scale epidemiological investigation of eczema has not been conducted. There is a lack of research on the prevalence of eczema and the related influencing factors in minority population areas of Xinjiang, and considerably less research on the risk factors of eczema in preschool children.

Therefore, considering the actual situation and specific environmental conditions in Urumqi, this survey was conducted in August 2019 in 60 kindergartens in Urumqi's six districts: Xinshi, Saybag, Tian Shan, Shuimugou, Toutunhe, and Midong. We interviewed parents of 8153 preschool children regarding their indoor living conditions and the prevalence of eczema. The risk factors influencing the prevalence of eczema in preschool children were investigated with the intention to identify relevant indoor environmental factors that can affect childhood eczema. The results of this survey are summarized and analysed to provide recommendations for future prevention and control of eczema in preschool children in Xinjiang.

\section{Methods \\ Subjects}

In this cross-sectional study, children were selected using a stratified random cluster sampling method from daycare centres in Urumqi. Stratified by six administrative areas in Urumqi (including Xinshi, Tian Shan, Toutunhe, Saybag, Midong, and Shuimogou), eight to twelve daycare centres in each administrative area were randomly selected. The parents of all children in each daycare centre were invited to participate in the questionnaire survey. The parents of 8153 children in 60 day-care centres received the questionnaire. The ethnic distribution of responders was predominantly Han, with fewer ethnic minority participants, mainly composed of Uyghurs, Kazaks and other unnamed minorities, accounting for approximately $13.1 \%$. The survey was conducted in August 2019.

\section{Questionnaire}

The questionnaire survey [5] was conducted in day-care centres, this was a 4-stage process as shown in Table S1. We contacted the Urumqi Education Bureau and the head of each kindergarten and conducted unified professional training for the teachers in charge of particular classes before the survey. The questionnaires were sent to the kindergartens, and the teachers distributed them to the parents, who were allowed to take the questionnaire home and were supposed to complete and return it within 1 week to the teacher in charge of the class. The teachers of all classes then sent the questionnaire to the head of the kindergarten. The head of the school collected all completed questionnaires from the kindergarten and sent them to the Urumqi Education Bureau.

The questionnaire was prepared in accordance with the ALLHOME-2 in Naydenov's [10] doctoral thesis and the questionnaire used by Bornehag in the Dampness in Buildings and Health survey study [11], with minor revisions based on specific conditions in China and Urumqi. The survey had the following six components: (1) demographic characteristics, including sex, ethnicity, education level and home address; (2) feeding status, including whether the child is an only child, whether the child was breastfed, breastfeeding duration, and the age at which the child attended kindergarten; (3) health conditions of the child and family members, including wheezing, asthma, pneumonia, allergic rhinitis and other related symptoms; (4) living environment for the child, including the type of housing, whether it is furnished, and the presence of new furniture, ventilation, and smoke extraction; (5) living habits, including animals, plants, frequency of cleaning, and smoking habit of the child's family members; and (6) eating habits, including type and frequency of food consumption. The completed questionnaires were investigated by two or more trained members of the team and incomplete questionnaires were eliminated.

Eczema was considered to be present if parents reported a clear diagnosis. The frequency of cleaning the child's room was categorized as frequent if cleaning occurred at least twice a week, occasional if cleaning occurred less than twice a week but more than once every 2 weeks, and rare if cleaning occurred less than once every 2 weeks [12]. Passive smoking refers to the exposure of a non-smoker to smoke from a lit cigarette or smoke exhaled by a smoker at least 1 day per week [13].

\section{Statistical analyses}

A database was created using the EpiData software (version 3.1). A single-factor $\chi 2$ test was performed using the SPSS software (version 25.0). Variables that were significant in the single-factor $\chi^{2}$ test were selected for multivariable logistic regression analysis. A multivariable 
logistic regression model was used to analyse potential eczema risk factors. The factors with odds ratio $>1$ as those that increased the risk of the eczema. $P<0.05$ was considered statistically significant.

\section{Results}

A total of 8153 preschool children were surveyed in this study (Table 1). The total number of people investigated was 10,000 , yielding a response rate of $81.5 \%, 1847$ children with incomplete responses to the questionnaire were excluded. The child cohort comprised 4235 (51.9\%) boys and 3918 (48.1\%) girls. The youngest and the oldest child were 2 years and 7.83 years old, and the average age was $5.27 \pm 1.10$ years. There were 7081 Han Chinese, accounting for $86.9 \%$ of the total, and 1072 belonging to other ethnic groups, accounting for $13.1 \%$ of the total.

The proportion of children who had recurrent rashes for 6 months in the past 12 months was $2.3 \%$, with no significant differences between characteristics (all $P>$ 0.05 ); $7.8 \%$ had previous history (prior to 12 months) of recurrent rash for 6 months, with higher incidence in boys than in girls $(P<0.05)$. The prevalence of participants with confirmed eczema was $12.0 \%$, with $9.7 \%$ in Han Chinese and $12.3 \%$ in other ethnic groups. Moreover, there was higher incidence of eczema in children delivered through caesarean section than those having vaginal delivery delivery, and in only children than in children with siblings (all $P<0.05)$ (Table 1).

The survey revealed the following major environmental risk factors that can influence development of eczema in preschool children: purchase and use of new furniture and furnishings; mould or dampness in the living environment of mother before and during pregnancy and child's first year; air conditioning; windows being open while sleeping; the presence of cockroaches, flies, or mosquitoes in the dwelling currently and during child's first year; pets or flowering plants in the dwelling; passive smoking in the home environment currently, during the child's first year and mother's pregnancy; frequency of room cleaning; and family history of eczema (all $P<0.05$ ) (Table 2).

The variables that were predicted to have a significant effect in the single-factor analysis together with whether the child had eczema as the dependent variable $(0=$ no; $1=$ yes) were included in our multivariable logistic regression analysis. Eight variables that showed significant effects in the logistic regression model were associated with the onset of eczema. Among these, delivery method $(\mathrm{OR}=1.18,95 \% \mathrm{CI}=1.03-1.36)$, only child $(\mathrm{OR}=1.36$, $95 \% \mathrm{CI}=1.18-1.57)$, presence of mould or dampness in the mother's home before pregnancy $(\mathrm{OR}=1.53,95 \% \mathrm{CI}$ $=1.17-2.00)$, presence of flies or mosquitoes $(\mathrm{OR}=$ $1.31,95 \% \mathrm{CI}=1.10-1.55)$, pets in the dwelling currently

Table 1 Prevalence of eczema among preschool children with different characteristics in Urumqi $(n=8153)$

\begin{tabular}{|c|c|c|c|c|c|c|c|c|c|c|}
\hline Characteristics & $\begin{array}{l}\text { Number } \\
\text { of } \\
\text { people } \\
\text { surveyed }\end{array}$ & $\begin{array}{l}\text { Number of cases of } \\
\text { recurrent rashes for } \\
6 \text { months in the past } \\
12 \text { months }\end{array}$ & $\begin{array}{l}\text { Percentage } \\
\text { (\%) }\end{array}$ & $P$ & $\begin{array}{l}\text { Number of } \\
\text { previous cases } \\
\text { of recurrent } \\
\text { rash for } 6 \\
\text { months }\end{array}$ & $\begin{array}{l}\text { Percentage } \\
\text { (\%) }\end{array}$ & $P$ & $\begin{array}{l}\text { Number of } \\
\text { confirmed } \\
\text { eczema } \\
\text { cases }\end{array}$ & $\begin{array}{l}\text { Percentage } \\
\text { (\%) }\end{array}$ & $P$ \\
\hline \multicolumn{11}{|l|}{ Sex } \\
\hline Boys & 4235 & 103 & 2.4 & 0.69 & 364 & 8.6 & $<0.01$ & 530 & 12.5 & 0.12 \\
\hline Girls & 3918 & 90 & 2.3 & & 271 & 6.9 & & 447 & 11.4 & \\
\hline \multicolumn{11}{|l|}{ Nationality } \\
\hline Han Chinese & 7081 & 172 & 2.1 & 0.35 & 567 & 8.0 & 0.06 & 873 & 12.3 & 0.01 \\
\hline Other & 1072 & 21 & 0.3 & & 68 & 6.3 & & 104 & 9.7 & \\
\hline \multicolumn{11}{|l|}{ Age (years) } \\
\hline $2-4$ & 1033 & 31 & 3.0 & 0.34 & 83 & 8.0 & 0.93 & 112 & 10.8 & 0.48 \\
\hline $4-6$ & 4828 & 108 & 2.2 & & 372 & 7.7 & & 585 & 12.1 & \\
\hline $6-8$ & 2292 & 54 & 2.4 & & 180 & 7.9 & & 280 & 12.2 & \\
\hline \multicolumn{11}{|l|}{ Mode of birth } \\
\hline $\begin{array}{l}\text { Normal } \\
\text { childbirth }\end{array}$ & 4187 & 97 & 2.3 & 0.76 & 313 & 7.5 & 0.28 & 449 & 10.7 & $<0.01$ \\
\hline $\begin{array}{l}\text { Cesarean } \\
\text { delivery }\end{array}$ & 3966 & 96 & 2.4 & & 322 & 8.1 & & 528 & 13.3 & \\
\hline \multicolumn{11}{|l|}{ Only child } \\
\hline Yes & 4569 & 112 & 2.5 & 0.57 & 374 & 8.2 & 0.13 & 605 & 13.2 & $<0.01$ \\
\hline No & 3584 & 81 & 2.2 & & 261 & 7.3 & & 372 & 10.4 & \\
\hline Totals & 8153 & 193 & 2.4 & & 635 & 7.8 & & 977 & 12.0 & \\
\hline
\end{tabular}


Table 2 Single-factor analysis of eczema and indoor environmental variables ( $n=8153)$

\begin{tabular}{|c|c|c|c|}
\hline \multirow[t]{2}{*}{ Factors } & \multicolumn{3}{|c|}{ Diagnosed with eczema } \\
\hline & Number of cases & $\%$ & $P$ \\
\hline \multicolumn{4}{|l|}{ Housing area } \\
\hline$<75 \mathrm{~m} 2$ & 239 & 12.1 & \multirow[t]{2}{*}{0.91} \\
\hline$\geq 75 \mathrm{~m} 2$ & 738 & 12.0 & \\
\hline \multicolumn{4}{|c|}{ Carpeting or mats in the home } \\
\hline Yes & 133 & 13.9 & \multirow[t]{2}{*}{0.06} \\
\hline No & 844 & 11.7 & \\
\hline \multicolumn{4}{|c|}{ Acquisition of new furniture in the dwelling of mother pre-pregnancy } \\
\hline Yes & 255 & 14.3 & \multirow[t]{2}{*}{$<0.01$} \\
\hline No & 722 & 11.3 & \\
\hline \multicolumn{4}{|c|}{ Renovation of the dwelling of mother pre-pregnancy } \\
\hline Yes & 182 & 15.2 & \multirow[t]{2}{*}{$<0.01$} \\
\hline No & 795 & 11.4 & \\
\hline \multicolumn{4}{|c|}{ Mold or dampness in the dwelling of mother pre-pregnancy } \\
\hline Yes & 176 & 20.1 & \multirow[t]{2}{*}{$<0.01$} \\
\hline No & 801 & 11.0 & \\
\hline \multicolumn{4}{|c|}{ Acquisition of new furniture in the dwelling of mother during pregnancy } \\
\hline Yes & 135 & 15.5 & \multirow[t]{2}{*}{$<0.01$} \\
\hline No & 842 & 11.6 & \\
\hline \multicolumn{4}{|c|}{ Renovation of the dwelling of mother during pregnancy } \\
\hline Yes & 100 & 17.0 & \multirow[t]{2}{*}{$<0.01$} \\
\hline No & 877 & 11.6 & \\
\hline \multicolumn{4}{|c|}{ Mold or dampness in the dwelling of mother during pregnancy } \\
\hline Yes & 137 & 20.1 & \multirow[t]{2}{*}{$<0.01$} \\
\hline No & 840 & 11.2 & \\
\hline \multicolumn{4}{|c|}{ Purchase of new furniture in the dwelling during the child first year } \\
\hline Yes & 117 & 16.0 & \multirow[t]{2}{*}{$<0.01$} \\
\hline No & 860 & 11.6 & \\
\hline \multicolumn{4}{|c|}{ Renovation of the dwelling during the child first year } \\
\hline Yes & 85 & 17.5 & \multirow[t]{2}{*}{$<0.01$} \\
\hline No & 892 & 11.6 & \\
\hline \multicolumn{4}{|c|}{ Mold or dampness in the dwelling during the child first year } \\
\hline Yes & 116 & 19.0 & \multirow[t]{2}{*}{$<0.01$} \\
\hline No & 861 & 11.4 & \\
\hline \multicolumn{4}{|c|}{ Drying bedding } \\
\hline Yes & 883 & 12.1 & 0.37 \\
\hline No & 94 & 11.0 & \\
\hline Use of air con & & & \\
\hline Yes & 337 & 13.2 & 0.02 \\
\hline No & 640 & 11.4 & \\
\hline Open window & & & \\
\hline Yes & 893 & 12.4 & $<0.01$ \\
\hline No & 84 & 8.9 & \\
\hline
\end{tabular}


Table 2 Single-factor analysis of eczema and indoor environmental variables ( $n=8153)$ (Continued)

\begin{tabular}{|c|c|c|c|}
\hline \multirow[t]{2}{*}{ Factors } & \multicolumn{3}{|c|}{ Diagnosed with eczema } \\
\hline & Number of cases & $\%$ & $P$ \\
\hline \multicolumn{4}{|l|}{ Cockroaches } \\
\hline Yes & 319 & 14.2 & \multirow[t]{2}{*}{$<0.01$} \\
\hline No & 658 & 11.1 & \\
\hline \multicolumn{4}{|c|}{ Flies or mosquitoes } \\
\hline Yes & 778 & 13.4 & \multirow[t]{2}{*}{$<0.01$} \\
\hline No & 199 & 8.5 & \\
\hline \multicolumn{4}{|c|}{ Pets in the child's current dwelling } \\
\hline Yes & 203 & 17.5 & \multirow[t]{2}{*}{$<0.01$} \\
\hline No & 774 & 11.1 & \\
\hline \multicolumn{4}{|c|}{ Flowering plants in the child's current dwelling } \\
\hline Yes & 343 & 14.0 & \multirow[t]{2}{*}{$<0.01$} \\
\hline No & 634 & 11.1 & \\
\hline \multicolumn{4}{|c|}{ Keeping pets in the dwelling during the child first year } \\
\hline Yes & 136 & 20.6 & \multirow[t]{2}{*}{$<0.01$} \\
\hline No & 841 & 11.2 & \\
\hline \multicolumn{4}{|c|}{ Flowering plants in dwelling during the child first year } \\
\hline Yes & 274 & 14.7 & \multirow[t]{2}{*}{$<0.01$} \\
\hline No & 703 & 11.2 & \\
\hline \multicolumn{4}{|c|}{ Passive smoking in the dwelling of child } \\
\hline Yes & 417 & 14.0 & \multirow[t]{2}{*}{$<0.01$} \\
\hline No & 560 & 10.8 & \\
\hline \multicolumn{4}{|c|}{ Passive smoking in the dwelling during the child first year old } \\
\hline Yes & 359 & 14.6 & \multirow[t]{2}{*}{$<0.01$} \\
\hline No & 618 & 10.9 & \\
\hline \multicolumn{4}{|c|}{ Passive smoking in the dwelling of mother during pregnancy } \\
\hline Yes & 315 & 15.3 & \multirow[t]{2}{*}{$<0.01$} \\
\hline No & 662 & 10.9 & \\
\hline \multicolumn{4}{|c|}{ Frequency of room cleaning } \\
\hline Regularly & 809 & 11.6 & \multirow[t]{3}{*}{0.02} \\
\hline Occasionally & 156 & 14.5 & \\
\hline Very seldom & 12 & 14.6 & \\
\hline \multicolumn{4}{|c|}{ Family history of eczema } \\
\hline Yes & 252 & 30.3 & \multirow[t]{2}{*}{$<0.01$} \\
\hline No & 725 & 8.9 & \\
\hline
\end{tabular}

$(\mathrm{OR}=1.23,95 \% \mathrm{CI}=1.01-1.51)$, pets in the dwelling during child's first year $(\mathrm{OR}=1.45,95 \% \mathrm{CI}=1.14-1.85)$, and family history of eczema $(\mathrm{OR}=3.53,95 \% \mathrm{CI}=2.98-$ 4.19) were risk factors; ethnicity (not Han Chinese; OR $=0.77,95 \% \mathrm{CI}=0.61-0.96)$ was considered as a protective factor against eczema (Table 3).

\section{Discussion}

Eczema is a multivariable inflammatory skin disease, and the ISAAC study results suggested a median prevalence of eczema is $6.99 \%(0.95-22.5)$ in children aged 6-7 years in 132 centres [14]. The current study showed that $2.3 \%$ of preschool children aged 2-8 years in Urumqi, Xinjiang, reported symptom of recurrent rash in the past 12 months, $7.8 \%$ of children reported a previous history of recurrent rash for 6 months, and $12.0 \%$ of children reported having been diagnosed with eczema. Dampness in the living environment, the presence of flies or mosquitoes, and keeping pets indoors were risk factors for development of eczema. In a 2010 survey of preschool 
Table 3 Multifactorial logistic regression analysis of risk factors for eczema in preschool children in Urumqi $(n=8153)$

\begin{tabular}{|c|c|c|c|c|}
\hline Factors & Reference group & $P$ & OR & $95 \% \mathrm{Cl}$ \\
\hline Ethnicity & Han ethnic group & 0.02 & 0.77 & $0.61-0.96$ \\
\hline Mode of birth & Normal childbirth & 0.02 & 1.18 & $1.03-1.36$ \\
\hline Only child & No & $<0.01$ & 1.36 & $1.18-1.57$ \\
\hline Mildew or dampness in the mother's pre-pregnancy dwelling & No & $<0.01$ & 1.53 & $1.17-2.00$ \\
\hline Flies or mosquitoes & No & $<0.01$ & 1.31 & $1.10-1.55$ \\
\hline Pets in the child's current residence & No & 0.04 & 1.23 & $1.01-1.51$ \\
\hline Keeping pets in the child's residence when the child first year & No & $<0.01$ & 1.45 & $1.14-1.85$ \\
\hline Family history of eczema & No & $<0.01$ & 3.53 & $2.98-4.19$ \\
\hline
\end{tabular}

Abbreviations: $O R$ odds ratio, $\mathrm{Cl}$ confidence interval

children in 10 Chinese cities, Zhang et al. [5] found a prevalence of eczema in $13.3 \%$ of children in Urumqi in the past 12 months, and Wang et al. [6] found a previous prevalence of eczema in 15\% of children in 2011. These results along with the findings in other cities such as Wuhan [15] and Shenyang [4] indicate that Urumqi has a relatively low prevalence of eczema, which may be related to the environmental conditions in Urumqi.

Previous foreign studies found a significant association between father/mother having history of allergic disease and the development of eczema in infants $[16,17]$, suggesting the involvement of genetic factors in the development of eczema. Consistent with these findings, the present study substantiates family history of eczema as a risk factor for the development of eczema. The role of the filagrin gene $F L G$ has been suggested in the development of eczema; FLG is the main gene aggregates intermediate keratin filaments, and patients with acute eczema have reduced FLG activity $[18,19]$. Furthermore, animal studies conducted by Ge et al. [20] have suggested that acute eczema might be due to downregulated FLG expression and activation of protease-activated receptors and increased amount of transepidermal water loss in skin tissue, thereby disrupting skin barrier function and inducing eczema [20]. In addition, the FLG gene is prone to mutation, which can affect the integrity of the skin, thus reducing the skin's barrier capacity against allergens. Invasion by foreign substances stimulates the antigen-presenting cells to activate Th2 cells, which then induces metamorphosis [21, 22].

The present survey found that ethnicity is a protective factor for eczema, with ethnic minorities having a lower prevalence of eczema than the Han Chinese, which is similar to the results of study by Zhao et al. [23], which demonstrated that the incidence of eczema was higher in the Han Chinese than in the Uyghur population in the spring, autumn, and winter. However, owing to the lack of comparative studies between the Han Chinese and other ethnic groups, the reasons for this are not yet known. In this study, we speculate that the reason for different incidence rates of eczema is not only related to the genetic differences between the ethnic minorities and Han population, but also most likely to be associated with the living habits of different ethnic groups. The people in Xinjiang have unique dietary habits, particularly the ethnic minorities, who prefer pasta, beef and mutton and eat less seafood. Studies have proposed that consumption of allergenic foods such as seafood by mothers during pregnancy and delivery is a key risk factor for the development of eczema in infants [24]. Other factors may include rest and activity patterns and family and marital relationships of ethnic minorities in Xinjiang, which differ greatly from those of the Han Chinese [22]. Therefore, the risk of eczema is lower in ethnic minorities than in the Han Chinese. Regarding delivery method, a number of studies have confirmed that caesarean section significantly affect development and maturation of the neonatal immune system likely owing to the imbalance of intestinal flora of these infants, leading to immune dysfunction and hyperactive immune responses that eventually cause occurrence of conditions such as allergies and autoimmunity $[25,26]$. Consistent results were obtained in study by Azad et al. [27], the study demonstrated that the richness and diversity of the intestinal flora of infants delivered through caesarean section were low.

In addition, children also have a higher risk of eczema than only children, for which the cause is unknown. Although there is no literature to support this idea, we consider the possibility that non single children are more likely to have a fixed space for children's activities but an increased number of active people, compared to single children, resulting in a rise in the density of the population in the room.

The presence of pets is associated with an increased levels of endotoxins and allergens in the environment. Several other studies have recognised household pets as a risk factor for the development of asthma and allergic disease [11, 28-30]. Although many studies have shown that exposure to such substances early in life is effective in reducing the risk of asthma and allergic diseases [31, 32]. This difference may be related to the climatic conditions; Xinjiang has a dry climate, which is suitable for 
the dispersal of endotoxins and allergens in the environment. Children are exposed to high levels of endotoxins and allergens by prolonged contact with pets, and are at an increased risk of eczema. Therefore, pets should be avoided in children's homes. In addition, flies and mosquitoes were considered risk factors for the development of eczema in this study, but there is a lack of information on this aspect in China and abroad. In addition to eczema, other allergic diseases have been studied, however, the risk factors identified were the same, including the presence of pets causing onset of eczema and mosquito bites causing skin irritation. Since Xinjiang has a hot and dry climate, only few homes have damp problem. A humid environment is more suitable for mosquitoes to grow and breed along with the growth of dust mites and fungi in the house. According to Chen et al. [33], the second most common allergen for eczema is mould; the finding is consistent with the present study's outcome identifying the presence of mould or dampness indoors as risk factors. Thus, good pest control and dehumidification can help reduce the incidence of eczema in children.

As this survey employed a cross-sectional study and was still in its initial stages, there may have been some bias in the data collection process. Additional cross-sectional studies have weak power for causal demonstration, and follow-up should also unfold population-based case-control studies or cohort studies that clearly influence eczema in preschool children. The study is one of the few investigations on eczema among preschool children that have been conducted in Urumqi City, this may be of some guidance for the prevention and treatment of eczema among children.

\section{Conclusion}

Eczema has high risk among preschool children in Xinjiang, particularly the Han children. Delivery of children through caesarean section, presence of mould or moisture in the mother's home before pregnancy, presence of flies or mosquitoes in the dwelling currently, pets kept in the child's home currently, presence of pets during child's first year, and family history of eczema, are suggested as risk factors for the development of eczema in children.

\section{Abbreviations}

$\mathrm{Cl}$ : Confidence interval; OR: Odds ratio

\section{Supplementary Information}

The online version contains supplementary material available at https://doi. org/10.1186/s12887-021-02819-5.

Additional file 1.

\section{Acknowledgements}

Acknowledgement is given to National Natural Science Foundation of China (grant no. 81861138005) and National Natural Science Foundation of China (grant no. 81860179) for initiating the original research project. Researchers within the Department of Public health of Xinjiang Medical University and Urumqi Education Bureau must also be acknowledged for assisting with data collection.

\section{Authors' contributions}

HS designed the study, participated in the field investigation phase, and wrote the airicle. TW and GW onceptualized and designed the study, and investigated and revised the manuscript. JZ, LJ, SM, JY, ZY, MM, HD participated in the field investigation phase. All authors approved the final manuscript as submitted and agree to be accountable for all aspects of the work.

\section{Funding}

All phases of this study were supported by National Natural Science Foundation of China (grant no. 81861138005) and National Natural Science Foundation of China (grant no. 81860179).

\section{Availability of data and materials}

The datasets generated and/or analysed during the current study are not publicly available due the data belongs to the School of Public Health of Fudan University but are available from the corresponding author on reasonable request.

\section{Declarations}

Ethics approval and consent to participate

The study was approved by the research ethics committee of Fudan University (protocol no. IRB00002408 \& FWA00002399), and all parents and class teachers of the children under investigation have signed written informed consent.

\section{Consent for publication}

Not applicable.

\section{Competing interests}

The authors declare that they have no competing interests.

\section{Author details}

${ }^{1}$ School of Public Health, Xinjiang Medical University, Urumqi 830011, China. ${ }^{2}$ School of Nursing \& Health Management, Shanghai University of Medicine \& Health Sciences, No.279, Zhouzhu Highway, Pudong New District, Shanghai 201318, China. ${ }^{3}$ Cadre Health Center, People's Hospital of Xinjiang Uygur Autonomous Region, Urumai 830001, China. ${ }^{4}$ Department of Laboratory Medicine, Xinjiang Uyghur Autonomous Region Maternal and Child Health Hospital, Urumqi 830002, China.

Received: 3 December 2020 Accepted: 22 July 2021

Published online: 16 August 2021

\section{References}

1. Zheng J, Ni JC, Teng YH. Eczema etiology analysis and drug treatment in children. Strait Pharmaceutical J. 2014;26(5):96-7. https://doi.org/10.3969/j. issn.1006-3765.2014.05.051

2. Laura BK, Bornehag CG, Mikael H, et al. Eczema in early childhood is strongly associated with the development of asthma and rhinitis in a prospective cohort. BMC Dermatol. 2012;12(1):1-9. https://doi.org/10.11 86/1471-5945-12-11.

3. Schmitt J, Chen CM, Apfelbacher C, et al. Infant eczema infant sleeping problems, and mental health at 10 years of age: the prospective birth cohort study LIAS plus. Allergy. 2011;66(3):404-11. https://doi.org/10.1111/ j.1398-9995.2010.02487.X.

4. Guo X, Zhang L, Zhang HY, et al. Retrospective investigation of eczema and related factors in children aged 0 to 5 years in a kindergarten in Shenyang city. Maternal Child Health Care China. 2013;28(35):5863-5 DOI:CNKI:SUN: ZFYB.0.2013-35-048 
5. Zhang YP, Li BZ, Huang C, et al. Ten cities cross-sectional questionnaire survey of children asthma and other allergies in China. Chin Sci Bull. 2013; 58(34):4182-9. https://doi.org/10.1007/s11434-013-5914-z.

6. Bornehag CG, Sundell J, Hagerhed-Engman L, et al. 'Dampness' at home and its association with airway, nose, and skin symptoms among 10851 preschool children in Sweden: a crosssectional study. Indoor Air. 2005; 15(Suppl 10):48-55. https://doi.org/10.1111/j.1600-0668.2005.00306.x.

7. Sun $Y$, Sundell J. Life style and home environment are associated with racial disparities of asthma and allergy in Northeast Texas children. Sci Total Environ. 2011;409(20):4229-34. https://doi.org/10.1016/j.scitotenv.2011.07. 011.

8. Ring J, Kramer U, Schafer T, et al. Environmental risk factors for respiratory and skin atopy: results from epidemiological studies in former east and West Germany. Int Arch Allergy Immunol. 1999;118(2-4):403-7. https://doi. org/10.1159/000024148.

9. Wang $\mathrm{T}$, Zhao $\mathrm{ZH}$, Yao $\mathrm{H}$, et al. Housing characteristics and indoor environment in relation to children's asthma, allergic diseases and pneumonia in Urumqi, China [J]. Chin Sci Bull. 2013;58(34):4237-44. https:// doi.org/10.1007/s11434-013-5727-0.

10. Naydenov K, Popov T, Mustakov T, et al. The association of pet keeping at home with symptoms in airways,nose and skin among Bulgarian children. Pediatr Allergy Immunol. 2010;19(8):702-8. https://doi.org/10.1111/j.1399-3 038.2008.00721.x.

11. Bornehag CG, Sundell J, Sigsgaard T. Dampness in buildings and health (DBH):report from an ongoing epidemiological investigation on the association between indoor environmental factors and health effects among children in Sweden. Indoor Air. 2004;14(Suppl 7):59-66. https://doi. org/10.1111/j.1600-0668.2004.00274.X.

12. Wang $Q, X u C Y, X u D Q$, et al. Risks on asthma among city chiidren in China: a nationwide case-control study. Chin J Epidemiol. 2014;35(3):237-41. https://doi.org/10.3760/cma.j.issn.0254-6450.2014.03.004.

13. Luo LF, Chen JW, Luo MH, et al. Exposure to second-hand smoke and its influencing factors among 15-69 years old residents in Guangzhou city. Chin J Public Health. 2019;35(8):973-6. https://doi.org/10.11847/zgggws112 0915.

14. Fuertes E, Flohr C, Silverberg J, et al. Global associations between UVR exposure and current eczema prevalence in children from ISAAC phase three. J Investig Dermatol. 2017;137(6):1248-56. https://doi.org/10.1016/j.jid.2 017.02.966.

15. Zhang M, Wu Y, Yuan $Y$, et al. Effects of home environment and lifestyles on prevalence of atopic eczema among children in Wuhan area of China. Chin Sci Bull. 2013;58(34):4217-22. https://doi.org/10.1007/s11434-013-56856.

16. Parazzini F, Cipriani S, Zinetti C, et al. Perinatal factors and the risk of atopic dermatitis: a cort study. Pediatr Allergy Immunol. 2014;25(1):43-50. https:// doi.org/10.1111/pai.12165.

17. O'Donovan SM, O'B HJ, Murray DM, et al. Neonatal adiposity increases the risk of atopic dermatitis during the first year of life. J Allergy Clin Immunol. 2015;137(1):108-17. https://doi.org/10.1016/j.jaci.2015.05.035.

18. Riethmuller C, MA MA, Koppes SA, et al. Filaggrin breakdown products determine corneocyte conformation in patients with atopic dermatitis. J Allergy Clin Immunol. 2015;136(6):1573-1580.e2. https://doi.org/10.1016/j.ja ci.2015.04.042

19. Wang XW, Wang JJ, Gutowska-Owsiak D, et al. Deficiency of filaggrin regulates endogenous cysteine protease activity, leading to impaired skinbarrier function. Clin Exp Dermatol. 2017;42(6):622-31. https://doi.org/1 $0.1111 /$ ced. 13113 .

20. Ge YM, Hu YM, Ma T, et al. Function of skin barrier of acute eczema rats and its mechanism. Shandong Med J. 2019;59(11):30-3 DOI:CNKI:SUN:SDYY.0. 2019-11-011.

21. Maria Bohme MD. Cilla Soderhall, Inger Kull, et al. Filaggrin mutations increase the risk for persistent dry skin and eczema independent of sensitization. J Allergy Clin Immunol. 2012;129(4):1153-5. https://doi.org/10.1 016/j.jaci.2011.11.03.

22. Jocelyn M, Myers B, Gurjit K, et al. Eczema in early life: genetics,the skin barrier,and lessons learned from birth cohort studies. J Pediatr. 2010;157(5): 704-14. https://doi.org/10.1016/j.jpeds.2010.07.009.

23. Zhao YH, Abuduguli B, Sulaiman A. Comparison of clinical manifestations, morbidity factors, and quality of life of outpatient Uyghur and Han Chinese eczema patients in Urumqi, Xinjiang. Chin J Trauma Disabil Med. 2013; 21(12):324.
24. Fang SY, Chen X. Logistic regression analysis of factors influencing eczema in infants. Chin J Reprod Health. 2015;26(5):436-9. https://doi.org/10.3969/j. issn.1671-878X.2015.05.015.

25. Guan YZ. Influence of delivery mode on early immune system development of infants. Chin J Perinatal Med. 2011;14(1):32-4. https://doi.org/10.3760/ cma.j.issn.1007-9408.2011.01.010.

26. Miniello VL, Colasanto A, Diaferio L, et al. Mode of delivery and gut microbiota. Ital J Pediatr. 2014;40(Suppl 2):A17. https://doi.org/10.1186/18247288-40-S2-A17.

27. Azad MB, Konya T, Maughan $\mathrm{H}$, et al. Gut microbiota of healthy Canadian infants: profiles by mode of delivery and infant diet at 4 months. CMAJ. 2013;185(5):385-94. https://doi.org/10.1503/cmaj.121189.

28. Wang Y, Li S, Wang JY, et al. Influential factors of respiratory system symptoms and diseases of school children in Minqin county, Gansu province. J Environ Health. 2017;34(5):415-9 DOI:CNKI:SUN:HJYJ.0.2017-05011.

29. Zhao Y, Liu YQ, Liu MM, et al. Interactive effects of environmental tobacco smoke and pets ownership on respiratory diseases and symptoms in children. Chin J Pediatr. 2013;51(2):96-100. https://doi.org/10.3760/cma.j.issn. 0578-1310.2013.02.004.

30. Kramer MS, Matush L, Bogdanovich N, et al. The low prevalence of allergic disease in Eastern Europe: are risk factors consistent with the hygiene hypothesis? Clin Exp Allergy. 2009;39(5):708-16. https://doi.org/10.1111/j.13 65-2222.2009.03205.x

31. Kerkhof M, Wijga AH, Brunekreef $B$, et al. Effects of pets on asthma development up to 8 years of age:the PIAMA study. Allergy. 2009;64(8): 1202-8. https://doi.org/10.1111/j.1398-9995.2009.02016.x.

32. Wang $\Pi$, Shi HN, Liu Q, et al. Prevalence and influencing factors of asthma and wheezing among preschool children in Urumqi city: a cross-sectional survey. Chin J Public Health. 2021;37(2):260-4. https://doi.org/10.11847/ zgggws 1125733.

33. Chen YF, Qin SR, Wang ZY, et al. Analysis of allergen test results in 64 cases of children with eczema. Zhejiang J Lab Med. 2012;1:16 DOI:CNKI:SUN:JYYY. 0.2012-01-005.

\section{Publisher's Note}

Springer Nature remains neutral with regard to jurisdictional claims in published maps and institutional affiliations.
Ready to submit your research? Choose BMC and benefit from:

- fast, convenient online submission

- thorough peer review by experienced researchers in your field

- rapid publication on acceptance

- support for research data, including large and complex data types

- gold Open Access which fosters wider collaboration and increased citations

- maximum visibility for your research: over $100 \mathrm{M}$ website views per year

At $\mathrm{BMC}$, research is always in progress.

Learn more biomedcentral.com/submissions 